\title{
Decarburization of the Carbon Steel C45 During Annealing in Air
}

\section{Razogljičenje ogljikovega jekla C45 med žarjenjem na zraku}

\author{
Matija Zorc', Aleš Nagode', Milan Bizjak', Borut Zorc ${ }^{1,2}$ \\ ${ }^{1}$ Univerza v Ljubljani, Naravoslovnotehniška fakulteta, Aškerčeva 12, Ljubljana, Slovenia; matija.zorc@gmail.com; ales. \\ nagode@omm.ntf.uni-lj.si ; milan.bizjak@omm.ntf.uni-lj.si \\ ${ }^{2}$ Inštitut za varilstvo, Ptujska 19, Ljubljana, Slovenia; borut.zorc@i-var.si \\ * Inštitut za varilstvo, Ptujska 19, Ljubljana, Slovenia; borut.zorc@i-var.si
}

\begin{abstract}
In production it is necessary to achieve conditions that lead to the minimum decarburization of a steel product's surfaces. In this study, the hypo-eutectoid carbon steel $\mathrm{C} 45$ was annealed in air in the temperature range $T_{\mathrm{a}}=600-1100^{\circ} \mathrm{C}$. The annealing times were between $t_{\mathrm{a}}=1 / 2 \mathrm{~h}$ and $t_{\mathrm{a}}=2 \mathrm{~h}$. Different decarburizations occurred in different microstructures: ferrite-pearlite $\left(T_{\mathrm{a}}=600^{\circ} \mathrm{C}\right.$ and $700^{\circ} \mathrm{C}, T_{\mathrm{a}}<\mathrm{A}_{\mathrm{C} 1}$, no visible decarburization); ferrite-austenite $\left(T_{\mathrm{a}}=760^{\circ} \mathrm{C}, \mathrm{A}_{\mathrm{C} 1}<T \mathrm{a}<\mathrm{A}_{\mathrm{C} 3}\right.$, visible decarburization); austenite at the beginning, ferrite-austenite after the incubation period $\left(\mathrm{Ta}=850^{\circ} \mathrm{C}\right.$, $\mathrm{A}_{\mathrm{C} 3}<T_{\mathrm{a}}<912^{\circ} \mathrm{C}$, visible decarburization); and austenite $\left(T_{\mathrm{a}}=950^{\circ} \mathrm{C}\right.$ and $1100^{\circ} \mathrm{C}, T_{\mathrm{a}}>912^{\circ} \mathrm{C}$, visible decarburization and overheating of steel). The edges were more prone to decarburization and to overheating. Stress relieving, normalizing and annealing before quenching of the steel C45 can be carried out in air.
\end{abstract}

Key words: annealing, hypo-eutectoid steel, air, oxidation, decarburization

\section{Povzetek}

Tehnološko je nujno potrebno dosegati pogoje, ki vodijo k minimalnemu razogljičenju površin jeklenega izdelka. $V$ tej študiji smo podevtektoidno ogljikovo jeklo C45 žarili na zraku, v temperaturnem območju od $T_{\mathrm{a}}=600$ do $1100^{\circ} \mathrm{C}$. Čas žarjenja $t_{\mathrm{a}}$ je bil med $1 / 2$ ure in 2 urama. Različne stopnje razogljičenja so nastajale v različnih mikrostrukturah: ferit-perlit $\left(T_{\mathrm{a}}=600^{\circ} \mathrm{C}\right.$ in $700{ }^{\circ} \mathrm{C}, T_{\mathrm{a}}<\mathrm{A}_{\mathrm{C} 1}$, brez vidnega razogljičenja); ferit-avstenit $\left(T_{\mathrm{a}}=760^{\circ} \mathrm{C}, \mathrm{A}_{\mathrm{C} 1}<T_{\mathrm{a}}<\mathrm{A}_{\mathrm{C} 3}\right.$, vidno razogljičenje); avstenit na začetku, ferit-avstenit po inkubacijski dobi $\left(T_{\mathrm{a}}=850^{\circ} \mathrm{C}, \mathrm{A}_{\mathrm{C} 3}<T_{\mathrm{a}}<912^{\circ} \mathrm{C}\right.$, vidno razogljičenje); in v avstenitu $\left(T_{\mathrm{a}}=950^{\circ} \mathrm{C}\right.$ in $1100^{\circ} \mathrm{C}, T_{\mathrm{a}}>912^{\circ} \mathrm{C}$, vidno razogljičenje in pregretje jekla). Robovi so bili bolj nagnjeni k razogljičenju in pregretju. Žarjenje za odpravo napetosti, normalizacijo in žarjenje pred kaljenjem jekla C45 lahko glede na izsledke te študije izvajamo na zraku.

Ključne besede: žarjenje, podevtektoidno jeklo, zrak, oksidacija, razogljičenje 


\section{Introduction}

The oxidation and decarburization of the steel happen simultaneously during annealing in an oxidising atmosphere. Burning the carbon from the surface creates a difference in the carbon concentrations between the surface and the inner layers of the steel, leading to a constant diffusion of carbon from the inner layers towards the surface. This results in an unwanted, either completely or partially decarburized layer on the surface. In production it is necessary to achieve conditions that lead to the minimum decarburization of a steel product's surfaces. This either involves measures that prevent carbon from burning or annealing conditions under which the oxidation of steel is faster than the diffusion of carbon and therefore decarburization [1-3].

Decarburization is a process in which the carbon content in the surface of steel products decreases during the annealing when the steel is exposed to gases like $\mathrm{O}_{2}, \mathrm{CO}_{2}, \mathrm{H}_{2} \mathrm{O}$ and $\mathrm{H}_{2}$ at elevated temperatures [1-3]. The carbon on the surface of the steel reacts with these gases, producing $\mathrm{CO}$ and $\mathrm{CO}_{2}$ in an oxidizing atmosphere, or $\mathrm{CH}_{4}$ in a hydrogen atmosphere. Because of these reactions the carbon is able to escape from the steel, creating a surface layer with a lower carbon content. Concurrently, at $T>570^{\circ} \mathrm{C}$ in an oxidizing atmosphere iron generally oxidizes to form $\mathrm{FeO}$. Decarburization occurs when the chemical potential of the carbon in the atmosphere is lower than the equilibrium carbon potential that is needed to maintain the carbon content on the surface of the annealed steel. Decarburization is therefore a means of achieving the thermodynamic equilibrium between the steel and the atmosphere at the annealing temperature. Since this is not possible, burning of carbon on the surface creates and maintains the concentration gradient of the carbon between the surface and the interior of the steel product. This creates the conditions for the permanent diffusion of carbon from the interior into the surface of the steel. Because of this, longer annealing times mean thicker decarburized layers. Therefore, decarburization is a result of simultaneous oxidation and diffusion processes and is only visible when the diffusion of carbon is faster than the oxidation of the metal [1, 3-7]. There are many factors that affect the kinetics of decarburization [3-6]: the type of atmosphere and its flux, the time and temperature of the annealing, the proportion of carbon and other alloying elements in the steel, the condition of the surface (ground without scale, with scale), the microstructure of steel on the annealing temperature and the shape of the steel product (edges, notches, thin jutting parts and similar). Strong decarburization occurs in the vicinity of the rolled-in scale and in the vicinity of the cracks that were already present prior to the annealing $[1,2,6,8]$.

Depending on the conditions of annealing, decarburization can occur in three forms: as a ferrite surface layer (total decarburization), as a surface layer with a higher ferrite content than the non-decarburized parts (partial decarburization; here the content of ferrite gradually reduces with distance from the surface, to the point where the ferrite content is equal to that in the non-carburized parts) and as a combination of those two with ferrite surface layer and a partially decarburized layer below it [1-9]. A clearly visible partial decarburization with a higher ferrite content is a characteristic of a microstructure that was ferritic-pearlitic or pearlitic prior to annealing, while partial decarburization in quenched and tempered microstructures is not so clearly visible because of the needle-like microstructure $[9,10]$. A partially decarburized layer in sferoidize-annealed hyper-eutectoid tool steels is visible as a lamellar pearlite $[1,9]$. Compared to a non-decarburized material, the decarburized layer has a lower hardness (lower wear resistance, easier creation of surface damage and therefore the notch effect), a lower yield strength and tensile strength (possibility of surface-crack initiation because of overloading) and a lower fatigue strength (lower resistance to cyclic loading). In general, a fatigue crack will always be initiated in a ferrite surface layer $[1,6]$. It is known that in unfavourably oriented ferrite grains in (110) crystal planes even stresses that are lower than the yield strength can create conditions that make dislocation slips possible $[11,12]$. This means that a surface crack can initiate even when the surface is not damaged and at stresses that are acceptable for construction applications. All this being said, decarburization is 
usually considered as being a negative feature. Partial decarburization is, however, recommended in products produced from quenched and tempered steel. In this case the partial decarburization is acceptable as it slightly reduces the surface hardness and therefore increases the ductility and the resistance of the tempered martensite to brittle fracture [10]. In practice it is necessary to achieve conditions that result in the lowest possible decarburization of the surface, whether with procedures that prevent burning of the carbon on the surface or with conditions of annealing at which the oxidation of steel is faster than the carbon diffusion. These kinds of conditions can also be achieved in the air, which is otherwise unfavourable for annealing, but is cost-free.

This article combines theoretical analyses of oxidation with experimental results for the annealing of the hypo-eutectoid steel C45 (EN 10027-1) with a ground surface at different annealing temperatures and times in the air.

\section{Materials and Methods}

Research was conducted on non-alloyed, hypo-eutectoid carbon steel C45 with chemical composition as follows: $\mathrm{C}=0.43, \mathrm{Si}=0.22$, $\mathrm{Mn}=0.61, \mathrm{P}=0.034, \mathrm{~S}=0.014$, Fe: balance, all in wt.\%. The chemical composition was determined with an emission spectrometer. Steel's transformation temperatures are $\mathrm{A}_{\mathrm{C} 1}=735^{\circ} \mathrm{C}$ and $A_{C 3}=785{ }^{\circ} \mathrm{C}$ [13]. Suggested hot-working and heat-treatment temperatures are: forging at $T=850-1100{ }^{\circ} \mathrm{C}$, normalization at $T=840-870^{\circ} \mathrm{C}$, quenching from $T=820-860^{\circ} \mathrm{C}$, tempering at $T=530-670^{\circ} \mathrm{C}$, and spheroidizing at $T=650-700^{\circ} \mathrm{C}[2]$. The microstructure of the steel prior to annealing was ferritic-pearlitic. Annealing took place in the ambient air (humidity and consequently the effect of water vapour was neglected), which means in a gas mixture consisting of $78 \mathrm{vol} . \% \mathrm{~N}_{2}, 21 \mathrm{vol} . \% \mathrm{O}_{2}$ and 1 vol.\% of other gases. Annealing temperatures $\left(T_{\mathrm{a}}=600,700,760,850,950,1100\right.$; in $\left.{ }^{\circ} \mathrm{C}\right)$ and annealing times $\left(t_{\mathrm{a}}=1 / 2,1,2\right.$; in hours) were chosen congruently with the parameters for different types of annealing and hot working. From a metallurgical point of view this means decarburization in different microstructural states: ferrite-pearlite $\left(\mathrm{Ta}<\mathrm{A}_{\mathrm{C1}}\right)$, ferrite-austenite $\left(A_{\mathrm{C} 1}<T a<A_{C 3}\right)$, firstly austenite and ferrite-austenite after the incubation period $\left(\mathrm{A}_{\mathrm{C} 3}<T_{\mathrm{a}}<912{ }^{\circ} \mathrm{C}\right)$ and austenite $\left(T_{\mathrm{a}}>912^{\circ} \mathrm{C}\right)$. Samples were cut from a rod with a circular diameter $\mathrm{D}=135 \mathrm{~mm}$. They were in a cubic shape with average dimensions $40 \times 30 \times 17 \mathrm{~mm}$ and mass $\mathrm{m}=160 \mathrm{~g} \pm 20 \mathrm{~g}$. Prior to annealing, the masses of all the samples were measured and they were put into groups in a way so that the differences between the masses of all three samples that were annealed at the same temperature at different times were within 5 grams of each other. The surfaces of the samples were ground with $\mathrm{SiC}$ paper \#80 prior to the annealing to obtain a light metallic surface and thus were without any traces of oxides.

Each sample was annealed in a CARBOLITE laboratory electrical resistance furnace with a volume of $22 \mathrm{dm}^{3}$ with a static air atmosphere. The furnace has a programmer that allows it to set the temperature and annealing time as well as the heating rate to the annealing temperature. As the atmosphere heats faster than the sample, these temperatures were also controlled using a certified ALMEMO 2590-9 contact thermocouple, which was inserted into the furnace from a hole in the ceiling and was in contact with the sample from the side. Each sample was put in exactly the same place in the furnace (on a fireproof brick in the centre of the furnace). Before they were put in place, both the furnace and fireproof brick were heated to and stabilized at the annealing temperature. This guaranteed the same conditions and as fast as possible heating of each sample to its annealing temperature. The annealing time was being measured from the point when the sample or the control thermometer achieved a temperature of $T=T_{\mathrm{a}}-0.5{ }^{\circ} \mathrm{C}$. During the process the temperature changed in the range $T_{\mathrm{a}}-1^{\circ} \mathrm{C} \leq T \leq T_{\mathrm{a}}+3{ }^{\circ} \mathrm{C}$. After the annealing the samples were cooled out of the furnace in the air.

The decarburization depth was researched with optical microscopy. With this method it is possible to assess the totally decarburized layer (ferrite) and the partially decarburized one (higher content of ferrite than in non-decarburized steel) in the ferritic-pearlitic microstructure. Metallographic samples were wet-ground 
with a SiC paper up to \#4000, polished with a $1 / 4 \mu \mathrm{m}$ diamond paste and etched with $3 \%$ $\mathrm{HNO}_{3}$ in ethanol. Decarburization was assessed on the surfaces and edges (cutting area through the middle of the sample on a longer side) that were in contact with the air atmosphere (upper surface and sides). The depth of the visible decarburization was measured in two ways so that the results were sure to be correct. Firstly, a conventional approach on a microscope with a measuring ocular was used (because of the different magnifications, the length between two lines was measured with a micrometre plate), and secondly a computer version of this method was employed.

The surface of samples was ground prior to the annealing, so the effect of the scale on the kinetics of decarburization was nullified. It is a wellknown fact that a preliminary scale increases the intensity of decarburization [9].

\section{Results and discussion}

\section{Surface oxidation}

It is well known that a high temperature and longer annealing times caused a higher degree of surface oxidation. Although the oxidation process of iron and the composition of oxide layer at temperature range from $T=570$ do $700{ }^{\circ} \mathrm{C}$ are different as at $T>700{ }^{\circ} \mathrm{C}$ [14], based on the $\mathrm{Fe}-\mathrm{O}$ phase diagram is generally accepted that during steady-state annealing in air the oxide layer at $T>570^{\circ} \mathrm{C}$ is composed from three layers. At temperatures $T>700{ }^{\circ} \mathrm{C}$, the composition is, regardless of its depth, approximately $95 \% \mathrm{FeO}, 4 \% \mathrm{Fe}_{3} \mathrm{O}_{4}$ and $1 \% \mathrm{Fe}_{2} \mathrm{O}_{3}[6,11,14,15]$. The formation of different oxides in scale can be simplified according to the following chemical reactions $[2,16]$ :

$2 \mathrm{Fe}+3 / 2 \mathrm{O}_{2}=\mathrm{Fe}_{2} \mathrm{O}_{3}$

$3 \mathrm{Fe}+2 \mathrm{O}_{2}=\mathrm{Fe}_{3} \mathrm{O}_{4}$

$\mathrm{Fe}+1 / 2 \mathrm{O}_{2}=\mathrm{FeO}$

In our case most of the scale shattered and fell off the surface during the manipulation of the samples. Therefore, we were unable to accurately measure the thickness of the scales
Table 1. Calculated scale thickness on the surface of C 45 steel after annealing in the air.

\begin{tabular}{cccc} 
& \multicolumn{4}{c}{ Annealing time $\boldsymbol{t}(\mathbf{s}):$} \\
\hline $\begin{array}{c}\text { Temperature } \\
\boldsymbol{T}\left(\boldsymbol{~}^{\circ} \mathbf{C}\right)\end{array}$ & \multicolumn{4}{c}{ Scale thickness $\boldsymbol{d}_{\text {ox }}(\boldsymbol{\mu} \mathbf{m})$} \\
\hline 600 & 9 & 12 & 18 \\
\hline 700 & 29 & 41 & 58 \\
\hline 760 & 54 & 76 & 107 \\
\hline 850 & 118 & 168 & 237 \\
\hline 950 & 249 & 352 & 498 \\
\hline 1100 & 619 & 875 & 1238 \\
\hline
\end{tabular}

(we could only measure parts of scale on the samples that were annealed at $T_{\mathrm{a}}=1100{ }^{\circ} \mathrm{C}$ and $t_{\mathrm{a}}=2 \mathrm{~h}$, whose thickness was more than $1.0 \mathrm{~mm}$ ). Despite the fact that the oxidation of carbon steels is slower than the oxidation of iron [14], we assumed and simplified that oxidation of the carbon steel C45 is similar to the oxidation of iron, since the C45 steel contains a very small amount of alloying elements. Generally, at temperatures $\mathrm{T}>570{ }^{\circ} \mathrm{C}$ iron and carbon steel oxidation follows a parabolic law $[14,16]$ (in [15] it is stated that this occurs at $T=700-1000^{\circ} \mathrm{C}$ ). The thickness of the scale $d_{\text {ox }}$ that formed on the surface of the steel C45 was therefore calculated with an equation for iron oxidation $[6,15]$ :

$d_{o x}=\sqrt{6 \cdot t \cdot e^{\frac{-20392}{T}}},(\mathrm{~cm})$

where $t$ is time (s) and $T$ is the absolute annealing temperature (K). Table 1 shows calculated values of the scale that forms during the annealing of the hypo-eutectoid, non-alloyed steel C45 in air under our experimental annealing conditions. A comparison between our data and the experimental data for the oxidation of steel $55 \mathrm{SiCr}$ with 1.51 wt.\% $\mathrm{Si}$ and $0.70 \mathrm{wt} . \% \mathrm{Cr}$ shows that the steel $55 \mathrm{SiCr}$ oxidizes more slowly [5] [(a) $T_{\mathrm{a}}=750{ }^{\circ} \mathrm{C}$, $t_{\mathrm{a}}=1 \mathrm{~h} \rightarrow$ steel 55SiCr: $d_{\mathrm{ox}}=30 \mu \mathrm{m}$, equation 1: $d_{\mathrm{ox}}=69 \mu \mathrm{m}$; (b) $T_{\mathrm{a}}=1100^{\circ} \mathrm{C}, t_{\mathrm{a}}=1 \mathrm{~h} \rightarrow$ steel 55SiCr: $d_{\mathrm{ox}}=530 \mu \mathrm{m}$, equation 1: $d_{\mathrm{ox}}=875 \mu \mathrm{m}$; (c) $T_{\mathrm{a}}=1100^{\circ} \mathrm{C}, t_{\mathrm{a}}=2 \mathrm{~h} \rightarrow$ steel $55 \mathrm{SiCr}: d_{\text {ox }}=$ no 
data, equation $\left.1: d_{\mathrm{ox}}=1238 \mu \mathrm{m}\right]$, which is a result of the higher silicon content and the added chromium. Taking into account our approximate scale thickness measures after annealing at $T_{\mathrm{a}}=1100^{\circ} \mathrm{C}$ and $t_{\mathrm{a}}=2 \mathrm{~h}$, we concluded that equation (1) adequately describes the oxidation of non-alloyed steel C45 during the annealing in air.

\section{Surface decarburization}

During the annealing of steel at scale/steel interface a gas mixture of $\left(\mathrm{CO}+\mathrm{CO}_{2}\right)$ forms in the air by the reactions between carbon from steel and oxygen from air. However, simultaneously the carbon from the steel reacts also with previously formed $\mathrm{CO}_{2}$ according to Boudouard reaction [2]:

$2 \mathrm{C}+\mathrm{O}_{2}=2 \mathrm{CO}$

$\mathrm{C}+\mathrm{O}_{2}=\mathrm{CO}_{2}$

$\mathrm{C}+\mathrm{CO}_{2}=2 \mathrm{CO}$

The stability of $\mathrm{CO}$ increases with higher temperature; at pressure $\mathrm{p}=1 \mathrm{~atm}$, e.g. the ratio $\mathrm{CO} / \mathrm{CO}_{2}=1$ is achieved in a gas mixture at $T \approx 675^{\circ} \mathrm{C}$, while the ratio $\mathrm{CO} / \mathrm{CO}_{2}=4$ is achieved at $T \approx 750{ }^{\circ} \mathrm{C}$ [2]. Hence, with increasing temperature the reactions (d) and (f) prevail.

Decarburization only occurs if newly created gases are able to escape from the steel/scale boundary into the atmosphere. This means that the scale has to be permeable to these gases. The scale is permeable because of cracking and porosity. Non-porous scale becomes permeable above the critical thickness $d_{\mathrm{ox}} \approx 50 \mu \mathrm{m}$, when the tendency for cracking and peeling of the scale from the steel's surface occurs [11]. Scale with an overcritical thickness will crack because of combination of different phenomena: growing tensile stresses in wüstite (those generated due to local changes in composition of $\mathrm{FeO}$ ), reduction of plastic deformation ability of scale to conform the steel surface and sufficiently high pressure of carbon oxides (those created during decarburisation) in space between the scale and the steel. So, in the early stage of oxidation, the process of decarburization is suppressed. But when gaseous carbon oxides are free to escape into the atmosphere,

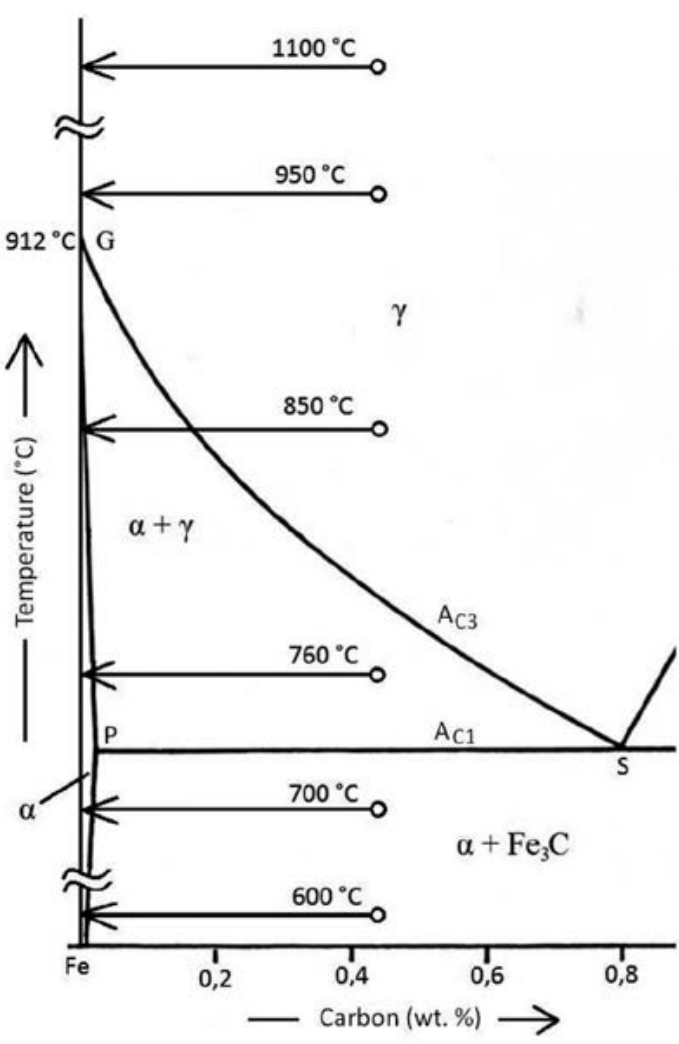

Figure 1: Microstructural changes for steel with C $=0.43$ wt.\% due to decarburization (schematically).

the processes of oxidation and decarburization will happen simultaneously. Decarburization causes the chemical composition and the microstructure of the affected layer of steel to change during the annealing.

For non-alloyed steels the process can be theoretically described with the left part of the $\mathrm{Fe}-\mathrm{Fe}_{3} \mathrm{C}$ phase diagram, which in the case of our steel with $\mathrm{C}=0.43$ wt.\% is shown in Figure 1, together with all the annealing temperatures. It is not necessary that all the microstructural changes will be seen. Visible decarburization actually occurs only when the decarburization and carbon diffusion in the steel are faster than the oxidation of the steel's surface.

The state of the flat surfaces after the annealing under different annealing conditions in the air is shown in Figure 2 and the state of the edges of the same samples is shown in Figure 3 (only the cases where states are different than those on the flat surfaces are shown). Neither the flat surfaces nor the edges show any signs of visible decarburization during annealing at $T_{\mathrm{a}} \leq 700{ }^{\circ} \mathrm{C}$ 

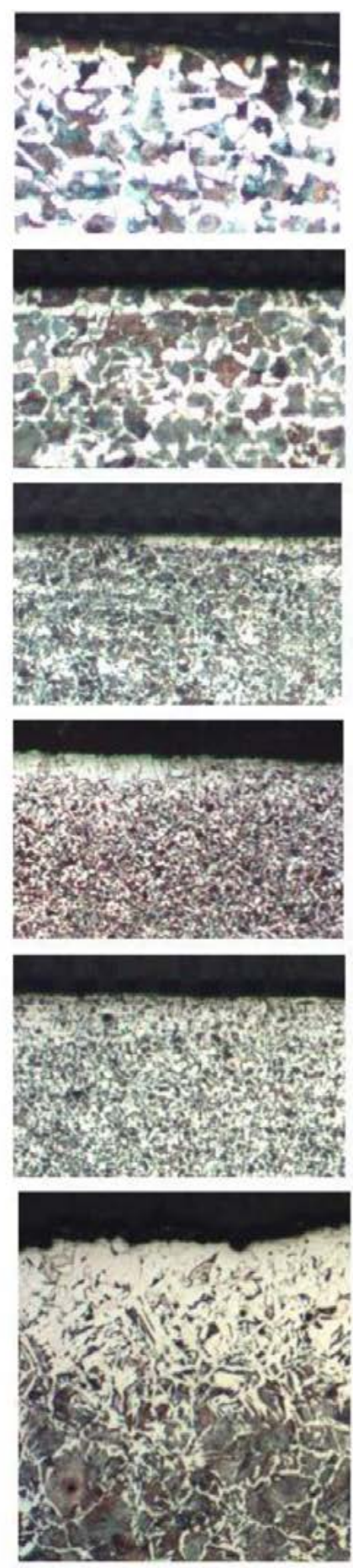

Dimension for all images

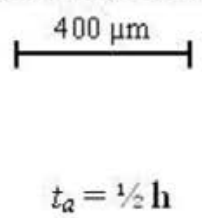

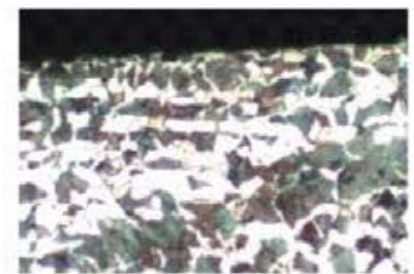
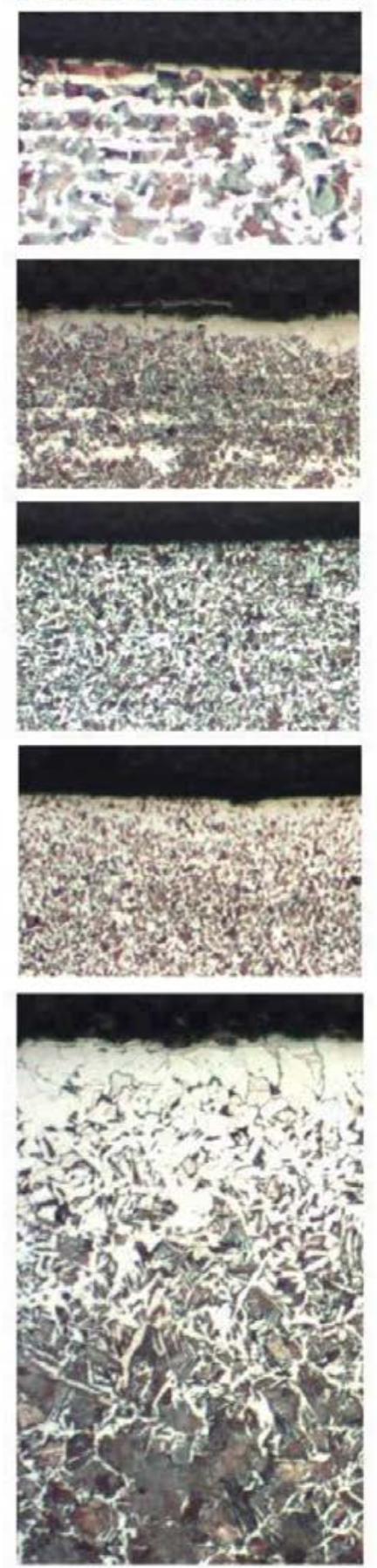

$$
t_{Q}=1 \mathrm{~h}
$$
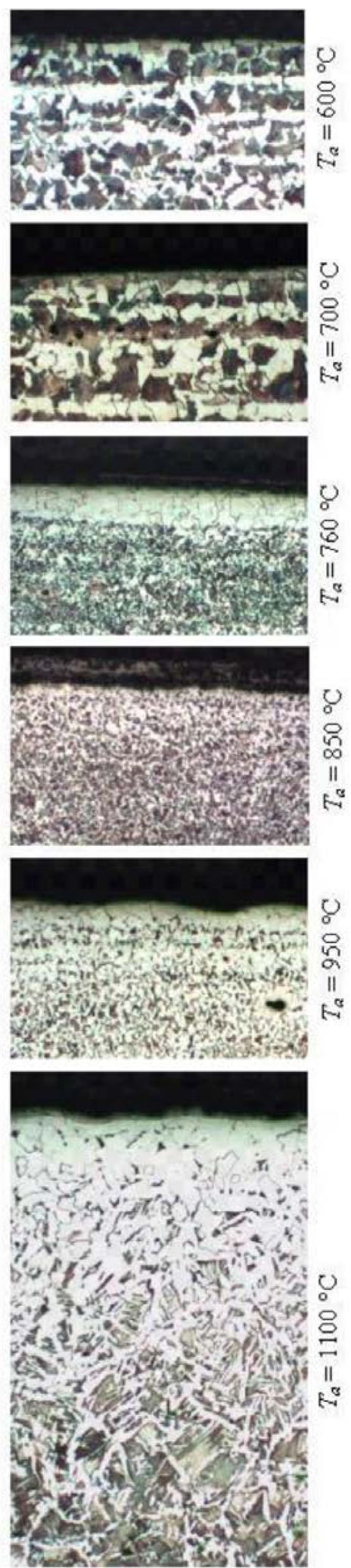

$$
t_{a}=2 \mathrm{~h}
$$

Figure 2: Microstructural state of the flat surfaces of the steel C45 after annealing in air. 


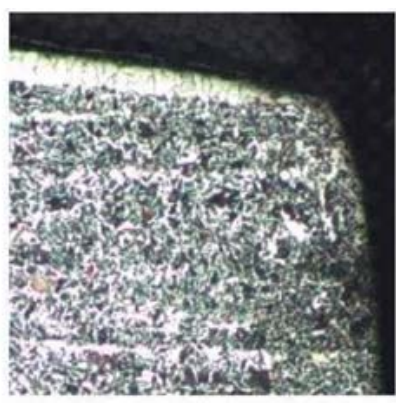

$T_{a}=760^{\circ} \mathrm{C}, t_{a}=1 \mathrm{~h}$

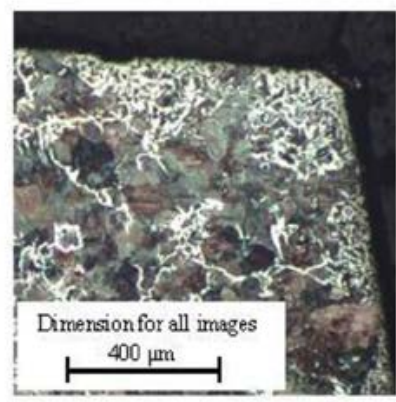

$T_{a}=950^{\circ} \mathrm{C}, t_{R}=1 / 2 \mathbf{h}$

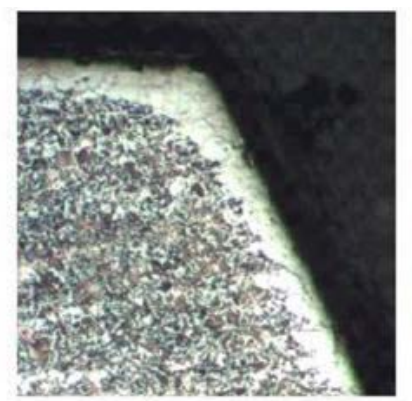

$T_{Q}=760^{\circ} \mathrm{C}, t_{R}=2 \mathrm{~h}$

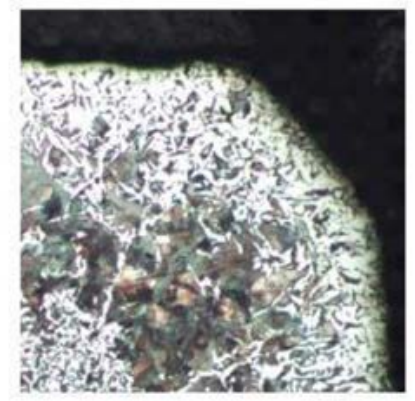

$T_{a}=950^{\circ} \mathrm{C}, t_{a}=1 \mathrm{~h}$

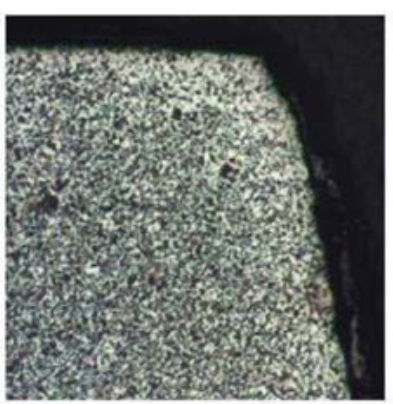

$T_{Q}=850^{\circ} \mathrm{C}, t_{Q}=2 \mathrm{~h}$

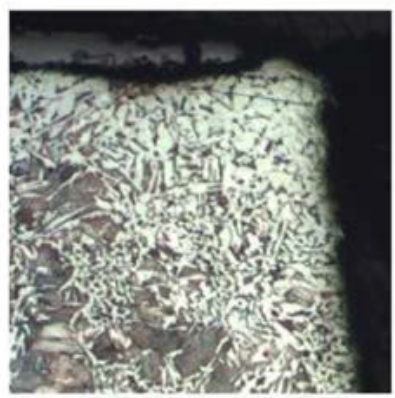

$T_{a}=950^{\circ} \mathrm{C}, t_{a}=2 \mathbf{h}$

Figure 3: Microstructural state of the edges of the steel C45 after annealing in air.

and $t_{\mathrm{a}} \leq 2 \mathrm{~h}$, which is in agreement with the data of other researchers $[4,5]$. It appears that the annealing time is too short, as according to some data and for a visible decarburization at $T_{\mathrm{a}}=700{ }^{\circ} \mathrm{C}$, the annealing times have to be up to $t_{\mathrm{a}}=32 \mathrm{~h}[5,17]$. It seems that under these annealing conditions the speed of decarburization is slower than the speed of oxidation, which is a consequence of the carbon being bound in the $\mathrm{Fe}_{3} \mathrm{C}$. Furthermore, it seems that the scale (thickness calculated at $d_{\mathrm{ox}}=58 \mu \mathrm{m}$ after the annealing at $T_{\mathrm{a}}=700^{\circ} \mathrm{C}$ and $t_{\mathrm{a}}=2 \mathrm{~h}$ ) is still compact enough to make it impermeable to gases, which means that decarburization does not begin.

The microstructure of steel during the annealing at temperatures $T_{\mathrm{a}}=760^{\circ} \mathrm{C}\left(\mathrm{A}_{\mathrm{C} 1}<T_{\mathrm{a}}<\mathrm{A}_{\mathrm{C} 3}\right)$ is austenitic-ferritic all the time, which is proven by the larger untransformed ferritic grains in the fine-grained ferritic-perlitic microstructure. Based on Figure 1 the surface becomes purely ferritic after a certain time. This was also proven with our results. After annealing for $t_{\mathrm{a}}=1 / 2 \mathrm{~h}$ the flat surface and the edges did not become decarburized (there is only one local decarburized area on the flat surface, which does not affect the surface properties and could be mistaken for untransformed ferrite). Oxidation of the surface in the first half an hour of annealing is obviously faster than the decarburization, while the scale is thin and compact (calculated thickness of the scale is $d_{\mathrm{ox}}=54 \mu \mathrm{m}$ ). The decarburized ferritic layer is clearly visible after annealing for $t_{\mathrm{a}}=1 \mathrm{~h}$ (calculated thickness of scale is $d_{\mathrm{ox}}=76 \mu \mathrm{m}$, so it already cracks and is permeable to gases), but there are also still parts of the surface without visible decarburization. After annealing for $t_{\mathrm{a}} \leq 1 \mathrm{~h}$ the edges did not become decarburized, which means that the edges also experienced only local decarburization. It seems that the factors which control the decarburization process under these conditions are local segregations in the steel and different oxidation speeds in different surface areas (decarburization on the edges should be more visible since the oxidation there is slower [18]; but on the other hand the slower oxidation on the edges means that the scale is still thin enough not to crack, which means it is still impermeable for gases, and therefore the edges were not decarburized). After annealing for $t_{\mathrm{a}}=2 \mathrm{~h}$ the decarburized layer is continuous, regardless of 
surface type, which shows that the oxidation is slower than the decarburization under these conditions. The calculated value of the scale's thickness is $d_{\mathrm{ox}}=107 \mu \mathrm{m}$, which means that it is permeable to gases. The visible surface ferritic layer of the surface already forming during the annealing in the ferritic-austenitic microstructure as a result of carbon concentrating in the austenite and carbon diffuses towards the surface through the ferritic layer, which consequently caused the simultaneous transformation of austenite into ferrite. This ferrite therefore frontally grows into the austenite (the only part where the austenite can become depleted with carbon is on the inner boundary with the ferritic surface layer; this is because of the carbon diffusion towards the surface through the ferritic layer).

When annealing at $T_{\mathrm{a}}=850{ }^{\circ} \mathrm{C}\left(\mathrm{A}_{\mathrm{C} 3}<T_{\mathrm{a}}<912{ }^{\circ} \mathrm{C}\right)$ the steel has the austenite microstructure at the beginning. After some time the surface layer becomes purely ferritic, which is a consequence of the carbon reacting with an oxidative atmosphere (the surface layer goes from the $\gamma$ area through the $\alpha+\gamma$ area to the $\alpha$ area) as shown in Figure 1. After annealing for ta $=1 / 2 \mathrm{~h}$ there is a visible locally limited total and partial decarburization, after $t_{\mathrm{a}}=1 \mathrm{~h}$ the decarburization is not visible, while there is only visible partial decarburization of the surfaces and the edges after annealing for $t_{\mathrm{a}}=2 \mathrm{~h}$ (it seems that the oxidation is already too fast for a ferritic layer to form). The scale is certainly permeable to gases (the calculated value of the scale after annealing for $t_{\mathrm{a}}=1 / 2 \mathrm{~h}$ is $d_{\mathrm{ox}}=118 \mu \mathrm{m}$ ). It seems that for the shortest times the speed of oxidation is slower than the speed of decarburization, while for the longest times the speed of oxidation of the flat surfaces is in general the same or higher than the speed of decarburization. Non-decarburized areas and locally decarburized areas are a consequence of segregations in the steel and different adherence of the scale on the steel's surface. After cooling, even the edges show the ferritic-pearlitic microstructure consisting of fine grains, which means that under these conditions there was still no overheating. While annealing at temperatures $T_{\mathrm{a}}=950{ }^{\circ} \mathrm{C}$ and $1100{ }^{\circ} \mathrm{C}\left(\mathrm{A}_{\mathrm{C} 3}<T_{\mathrm{a}}>912^{\circ} \mathrm{C}\right)$ the steel has an austenitic microstructure all the time. Due to decarburization the carbon concentration in the austenite (based on Figure 1) increases from the decarburized surface towards the interior of the sample in accordance with Fick's second law. After cooling the austenite transforms into ferrite and pearlite. At annealing temperatures and times of $T_{\mathrm{a}}=950{ }^{\circ} \mathrm{C}$ and $t_{\mathrm{a}}=1 / 2 \mathrm{~h}$ there is some local decarburization on the flat surfaces. For practical uses this level of decarburization is negligible. This, however, does not mean that there is no decarburization going on. Based on calculations the oxide layer is $d_{\mathrm{ox}}=83 \mu \mathrm{m}$ even after just 3 minutes of annealing, which means it quickly becomes permeable to gases. It seems that the speed of oxidation is the same or faster than the speed of the decarburization. Even when annealing for longer times flat surfaces will show only local decarburization, while the edges are already highly decarburized. It is, however, possible to find areas with the surface ferritic layer.

Another feature seen on the edges is overheating. This is proven by nests of pearlite grains and a Widmanstätten microstructure. It seems that annealing temperatures of $T_{\mathrm{a}}=950^{\circ} \mathrm{C}$ are already high enough for some austenite grains in non-alloyed steel to grow. This is also mentioned and shown in [1]. After annealing at $T_{\mathrm{a}}=1100^{\circ} \mathrm{C}$ the surface layer becomes highly decarburized, regardless of the annealing time. The same happens with the microstructure, which, regardless of the annealing time, consists of a purely ferritic layer on the surface and a Widmanstätten microstructure below. At this temperature it becomes clear that the diffusion of carbon on the austenite grain boundaries is of much higher magnitudes (because of the decarburized austenitic grain boundaries there will be polygonal ferrite present at these boundaries after cooling; Widmanstätten ferrite grows from this polygonal ferrite into the interior of the pearlitic grains) and that the decarburization speed is much higher than the rate of oxidation.

The edges are therefore more prone to decarburization than the flat surfaces, while they are also a critical area for overheating. In steel C45 at temperatures $T_{\mathrm{a}} \geq 950{ }^{\circ} \mathrm{C}$ this is responsible for a locally or globally present coarse-grain austenitic microstructure, which is shown by nests of pearlitic grains (Figure 3). This is certainly a consequence of locally converg- 


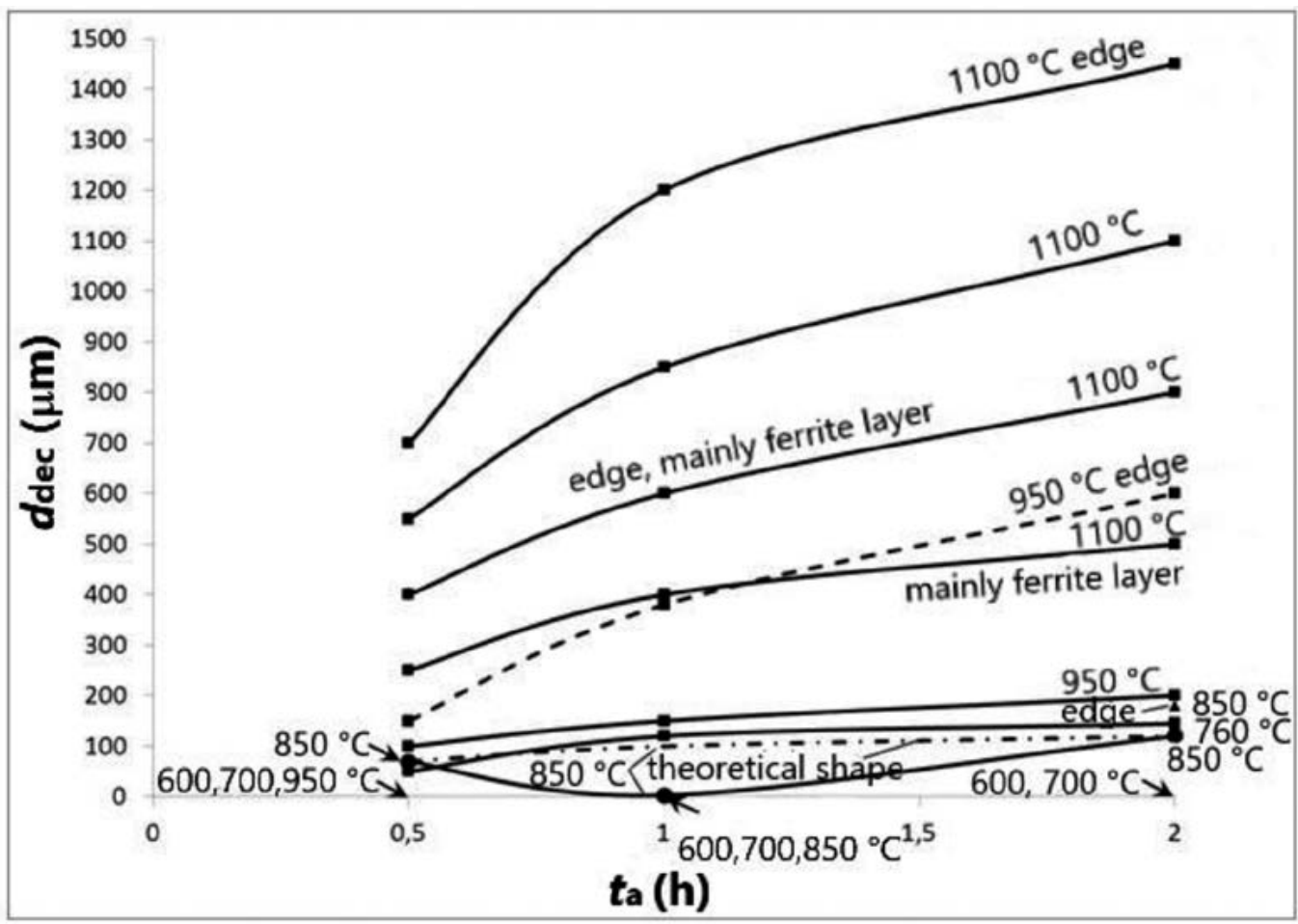

Figure 4: Maximum depth of visible decarburized layer $d_{\text {dec }}$ of steel C45 after annealing in air.

ing surfaces (edges are subjected to annealing temperatures for longer times than the flat surfaces) and different conditions for oxidation (it is usually of lower intensity than on the flat surfaces [18]). The conclusion is that different geometrical features affect the process of decarburization under the same annealing conditions. The measured maximum depths of the decarburization are shown graphically in Figure 4 . Our results are in accordance with the findings $[8,16]$ that decarburization follows a parabolic law like the oxidation. For the decarburization at $T_{\mathrm{a}}=850^{\circ} \mathrm{C}$ two curves are plotted. The dashed line shows the generally well-known parabolic shape of the decarburization, while the full line represents the real state of the decarburization obtained from the measurements. The results show that at this temperature the shorter time of annealing in the air is more critical than a longer time (on the surface a fully decarburized ferritic layer forms after annealing for $t_{\mathrm{a}}=1 / 2 \mathrm{~h}$, while the ferritic surface layer is not visible when annealed for longer times).

There is a time interval of annealing in the air when visible decarburization does not exist.
This is undoubtedly related to the oxidation rate of the surface, which is also confirmed by the results in $[19,20]$. In this case the decarburization of the steel was studied in an atmosphere consisting of $\mathrm{N}_{2}$ and 4 vol.\% natural gas in which a different amount of air was added. Under the following annealing conditions $\left(T_{\mathrm{a}}=850^{\circ} \mathrm{C}\right.$ in $t_{\mathrm{a}}=2 \mathrm{~h}$ and the content of air is less than 8 vol. \%) the decarburization increases. However, when more than 8 vol. \% of air was added a significant difference in the decarburization depths was found (the curve in the Figure 4 [20] is dashed and describes a theoretical process of decarburization), which is explained by surface oxidation. The oxidation and various impact factors (the chemical composition of the steel, the volume of the furnace chamber, different types of chamber furnace, i.e., with or without a fan, the ratio between the volume of the chamber and the sample, the air flux in the furnace, the air's humidity) are certainly a reason for the huge deviations in the decarburization depth measurements found in the literature. The effect of the humidity of the non-air atmospheres is known (if the humidity is higher, then the dew point is also higher, 
the carbon potential of the atmosphere is lower and the decarburization is stronger [20]). However, according to known facts (due to water vapour in air the adherence of the scale to the steel surface is better and thus, the oxidation rate is higher [14]; the oxidation rate of steel is two to three times higher in air supersaturated with moisture [21]) the visual decarburization in the wet air is supposed to be decreased in comparison to the dry air (the effect of the humidity might be important only in a certain temperature range).

\section{Conclusions}

In this research the decarburization of normalized, non-alloyed, hypo-eutectoid carbon steel C45 annealed in an air atmosphere was investigated. Based on the results it can be concluded:

- The rates of decarburization and oxidation for the surface increase with higher temperatures and longer annealing times. Compared to the flat surfaces, the edges had a higher degree of decarburization, in general. There was no visible decarburization of the surface of the C45 steel under some annealing conditions. These are: $T_{\mathrm{a}} \leq 700{ }^{\circ} \mathrm{C}$ for $t_{\mathrm{a}} \leq 2 \mathrm{~h}, T_{\mathrm{a}}=760{ }^{\circ} \mathrm{C}$ for $t_{\mathrm{a}}=1 / 2 \mathrm{~h}$ and $T_{\mathrm{a}}=850^{\circ} \mathrm{C}$ for $t_{\mathrm{a}}=1 \mathrm{~h}$. The rate of oxidation of the surface under these annealing conditions is higher than the rate of its decarburization. This means that stress relieving, normalizing and annealing for quenching can be carried out in air.

- Locally limited decarburization of the surface was discovered when annealing at $T_{\mathrm{a}}=760{ }^{\circ} \mathrm{C}$ for $1 / 2 \mathrm{~h}<t_{\mathrm{a}}<1 \mathrm{~h}, T_{\mathrm{a}}=850^{\circ} \mathrm{C}$ for $t_{\mathrm{a}}=1 / 2 \mathrm{~h}$ and $2 \mathrm{~h}$ and $T_{\mathrm{a}} \leq 950{ }^{\circ} \mathrm{C}$ for $1 / 2 \mathrm{~h}<t_{\mathrm{a}} \leq 2 \mathrm{~h}$. The speeds of oxidation and decarburization are approximately the same under these conditions, which means that one of the possible reason for locally decarburization is a consequence of segregations. This increases the activity of carbon in those areas (because silicon does not segregate a lot, the only other option in C45 steel is that these segregations have a lower manganese concentration than the rest of the steel). The occurrence of locally decarburized areas is time dependent until the global decarburization happened (in our case this happened at $T_{\mathrm{a}}=760^{\circ} \mathrm{C}, t_{\mathrm{a}}=2 \mathrm{~h}$ and $T_{\mathrm{a}}=1100^{\circ} \mathrm{C}$ ). A second, probably more possible reason for local decarburization could be a different adhesion of the scale to different parts of the steel's surface and local cracking of the scale. Under these annealing conditions it is necessary to introduce measures to prevent the oxidation and decarburization (for example, annealing in a protective atmosphere).

- Highest rates of decarburization occur during high-temperature annealing where the coarse austenite crystal grains also occur due to overheating. Those grown austenite grains lead to a coarse Widmanstätten ferritic-pearlitic microstructure at room temperature. When annealed at $T_{\mathrm{a}}=950{ }^{\circ} \mathrm{C}$ for $1 / 2 \leq t_{\mathrm{a}} \leq 2 \mathrm{~h}$, the areas that were most prone to overheating and decarburization were the edges. Other surfaces became prone to those when being annealed at $T_{\mathrm{a}}=1100^{\circ} \mathrm{C}$ for $t_{\mathrm{a}} \geq 1 / 2 \mathrm{~h}$. Under these annealing conditions it is necessary to introduce measures for the prevention of oxidation and decarburization.

\section{References}

[1] Schumann, H. (1983): Metallografie, 12. Auflage. Leibzig: WEB Deutscher Verlag für Grundstoffindustrie, $608 \mathrm{p}$.

[2] Kveder, A. (1972): Metalurški priročnik (Handbook of Metallurgy), Ljubljana: Tehniška založba Slovenije, $1471 \mathrm{p}$.

[3] Mardon, C. (1998): The austenitization and decarburization of high silicon spring steel. PhD Thesis, Christchurch: University of Canterbury; $103 \mathrm{p}$.

[4] Zhang, C.L., Zhou, L.I., Liu, Y.Z. (2013): Surface decarburization characteristics and relation decarburized types and heating temperature of spring steel 60Si2MnA. International Journal of Minerals, Metallurgy, and Materials, 20(8), pp. 720-724.

[5] Liu, Y., Zhang, W., Tong, Q., Wang, L. (2014): Effects of Temperature and Oxygen Concentration on the Characteristics of Decarburization of 55SiCr Spring Steel. ISIJ International, 54(8), pp. 1920-1926. 
[6] Zorc, M. (2016): Decarburization of non-alloy medium carbon steel during annealing in an air atmosphere (in Slovenian), Diploma Thesis, Ljubljana: University of Ljubljana, Faculty of Natural sciences and Engineering - Department of Materials and Metallurgy; $41 \mathrm{p}$.

[7] Mayott, S.W. (2010): Analysis of the Effect of Reduced Oxygen Atmospheres on the Decarburization Depth of 300M Alloy Steel, Master of Science Thesis, New York, Rensselaer Polytechnic Institute, Department of Materials Science and Engineering.

[8] Naumann, F.K. (1976): Das Buch der Schadensfälle. Stuttgart, Germany: Dr. Riederer-Verlag GmbH, 481 p.

[9] Vander Voort, G.F. (2015): Understanding and Measuring Decarburization. Advanced materials \& Processes, 173(2), pp. 22-27.

[10] Jaason, K., Peetsalu, P., Saarna, M., Kulu, P., Beilmann, J. (2016): Decarburization Effect on Hardened Strip Fastening Components. Materials Science, 22(1), pp.148-152.

[11] Vodopivec, F. (2002). Kovine in zlitine (Metals and Alloys), Ljubljana: Institute of Metals and Technology, $474 \mathrm{p}$.

[12] Zorc, B., Nagode, A., Kosec, B., Kosec, L. (2013): Elevator chain wheel shaft break analysis. Case Studies in Engineering Failure Analysis, 1(2), pp. 115-119.

[13] Atlas zur Wärmebehandlung der Stähle auf CD-ROM (2009); Düsseldorf: Verlag Stahleisen GmbH.

[14] Chen, R.Y., Yuen, W.Y.D. (2003): Review of the High-Temperature Oxidation of Iron and Carbon Steels in Air or Oxygen. Oxidation of Metals, 59(5/6), pp. 433-468.
[15] De Cooman, B.C., Speer, J.G. (2011): Fundamentals of Steel Product Physical Metallurgy, Englewood: AIST, $642 \mathrm{p}$.

[16] Grzesik, Z. (2003): Thermodynamics of Gaseous Corrosion. In ASM Handbook, Vol. 13A - Corrosion: Fundamentals, Testing, and Protection, Cramer, S.D., Covino Jr., B.S. (Eds.), Ohio: ASM International, Materials Park, pp. 90-96.

[17] Billings, G.A. (1966): Oxidation and Decarburization Kinetics of Iron-Carbon Alloys in Carbon Dioxide-Carbon Monoxide Atmosphere, Master of Science Thesis, Hamilton, Ontario: McMaster University; 120 p.

[18] Baud, J., Ferrier, A., Manenc, J., Bénard, J. (1975): The oxidation and decarburizing of Fe-C alloys in air and the influence of relative humidity. Oxidation of Metals, 9(1), pp. 69-97.

[19] Sebenji, F., Hakl, L., (1980). Corrosion of metals in theory and practice (in Serbian), Belgrade: Tehnička knjiga, $226 \mathrm{p}$.

[20] Stratton, P.F. (1984): Living with Furnace Atmosphere Contamination. Metal Science and Heat Treatment, 2, pp. 41-48.

[21] Parrish, G. (1999): Carburizing-Microstructures and properties. Ohio: ASM International: Materials Park, $247 \mathrm{p}$.

[22] Mladenović, S., Petrović, M., Rikovski, G. (1975). Handbook of chemical technology, Corrosion and protection of materials (in Serbian), Belgrade: IRO “RAD”, 484 p. 
